\title{
The impact of COVID-19 pandemic outbreak on the Egyptian firms' stock returns: evidence from emerging countries
}

\section{Mohamed Hamdy Awad Faculty of commerce - Cairo University Mohamed hamdy@foc.cu.edu.eg}

\section{Abstract}

The COVID-19 pandemic is considered one of the most severe contagious infectious experienced by the world during the $21^{\text {st }}$ century. This pandemic has economic, social, and psychological consequences that need years to recover again. Therefore, this paper aims to verify the effect of the COVID-19 pandemic on the Egyptian firms' stock returns. Using historical data of listed firms in EGX 30 index during the period from $16^{\text {th }}$ February 2020 to $21^{\text {st }}$ May 2020, the results reveal that stock returns across all listed firms in EGX 30 index have been significantly negatively affected of both the daily growth in total confirmed cases and in total confirmed deaths. In addition, Egyptian firms' stock returns are negatively associated with daily cumulative COVID-19 cases and positively to daily cumulative COVID-19 deaths.

Keywords: COVID-19 pandemic; stock returns; emerging countries; Egyptian firms. 
The impact of COVID-19 pandemic outbreak on the Egyptian firms' stock returns

Dr/ Mohamed Hamdy Awad

\section{Introduction}

Infectious diseases were not a result of the present moment, as the world was exposed in the $20^{\text {th }}$ century to some pandemics such as the Spanish flu in 1918، H2N2 in 1957 ('Asian flu') and H3N2 in 1968 ('Hong Kong flu') (Baldwin \& di Mauro, 2020). The Spanish flu is one of the most serious pandemics in the $20^{\text {th }}$, As the number of deaths resulting from it around the world reached approximately 50 million (Taubenberger \& Morens, 2006). The $21^{\text {st }}$ century the world has seen four pandemic outbreaks: Severe Acute Respiratory Syndrome (SARS) in 2002, N1H1 in 2009 ('bird flu'), Middle East Respiratory Syndrome (MERS) in 2012, and Ebola fever Virus which peaked in 2013-2014 (Baldwin \& di Mauro, 2020).

In addition to previous pandemics, the World Health Organization (WHO) reported late 2019 the first case of COVID-19 in Wuhan China, a virus that belongs to the family known as corona viruses (Liu et al., 2020). The COVID-19 pandemic can be described as a 'black swan' as it was expected that the economic effects would be significant (AlAli, 2020). and it spreading at high speeds around the world, leading to a huge number of infections and deaths in over 200 countries (Zaremba et al., 2020; Papadamou et al., 2020). the outbreak COVID- 19 has Distorted the concept of globalization by forcing countries to close down borders, preventing natural flows of goods, capital, and humans, and at least temporarily 
The impact of COVID-19 pandemic outbreak on the Egyptian firms' stock returns

Dr/ Mohamed Hamdy Awad

shutdowns of business and production (Barua, 2020). Therefore, COVID-19 epidemic has thus already caused substantial human suffering and major economic damage (OECD, 2020a)

From the foregoing, the global growth outlook is highly unpredictable since the economic effect depends on unknown variables that interact in ways that are difficult to predict. so, the universal economy is estimated to contract sharply with -3 percent in 2020, much inferior to the 2008-09 financial crisis (IMF, 2020). Furthermore, OECD (2020a) suggested global annual GDP growth is projected to fall to 2.4 percent overall in 2020, compared to 2.9 percent in 2019. Fernandes (2020) also projected that, during the pandemic period, the average global GDP growth could decline between 3-5 percent.

In Egypt, with the outbreak of COVID-19 all schools and universities, monuments, restaurants, churches, mosques, and their attachments, cultural and touristic events were abrogated, and the government prohibited religious prayers and other widespread public meetings. An overnight curfew was enforced between $8 \mathrm{pm}$ and 6 am local time. In addition to all airports are closed and air travel has been suspended, including international flights. The Government has also reduced the number of employees in the public sector by half (OECD, 2020b). All the measures are taken by the Egyptian state to Containment the crisis have had economic consequences such as a decrease in the volume of foreign remittances, a decrease in Tourism and 
The impact of COVID-19 pandemic outbreak on the Egyptian firms' stock returns

Dr/ Mohamed Hamdy Awad

Suez Canal receipts, and deterioration of the volume of foreign direct investment. As a result, GDP growth projections in Egypt may hit 1.3 percent at year-end, compared with 5.6 percent in 2019 (AmCham Egypt, 2020).

The COVID-19 pandemic also affects financial markets which play a significant role in each country's economic growth. Many major events, including news, ecological, and political events, affect financial markets (Al-Awadhi et al., 2020). Because of this, Returns on the stock market can also respond to Pandemic Illnesses, for example, SARS outbreak was occurring Between January 2013 and the middle of March 2013, the Dow Jones Index fell roughly $15 \%$ from peak to trough due to fear and uncertainty surrounding the virus (Yan et al., 2020). Spanish flu also has a negative impact on US stock markets during the pandemic's early months (Velde, 2020). The global economy has been estimated to have lost approximately $\$ 40$ billion during the SARS-CoV outbreak in China from 2002 to 2003 (Ayittey et al., 2020). In many countries over different financial periods, the following studies have identified the negative impact of COVID-19 on stock markets returns (Liu et al., 2020; Alfaro et al., 2020; Alber, 2020; He et al., 2020; Çitak et al., 2020; Adenomon et al., 2020; AlAwadhi et al., 2020). The key Egyptian Stock Exchange index (EGX30) declined 39 percent, as a result of the outbreak of COVID-19 (OECD, 2020b).

The purpose of this paper is therefore to analyze the effect of 
The impact of COVID-19 pandemic outbreak on the Egyptian firms' stock returns

Dr/ Mohamed Hamdy Awad

COVID-19 on Egyptian firms' stock returns. Two proxies for evaluating the COVID-19 outbreak were used to achieve this aim. (1) Daily growth in total confirmed cases and daily growth in total confirmed deaths. (2) Daily cumulative COVID-19 cases and deaths. Using the panel data regression technique, the findings indicate that both daily growth in total reported cases, as well as in total cases of death due to COVID-19, have a substantial negative effect on stock returns for all firms. In addition, stock returns are negatively related to daily cumulative COVID-19 cases and positively to daily cumulative COVID-19 deaths.

Additional tests on the effect of the COVID-19 epidemic on the economic sectors show that the COVID-19 epidemic has a negative impact on stock returns in the following sectors: realestate, non-bank financial services, and basic resources. Given the small number of firms in the remaining sectors in the EGX 30 index, this paper did not discuss the effect of the COVID-19 outbreak on those sectors. The additional tests also suggest that high stocks of market capitalization have a significant positive effect on returns compared to low stocks of market capitalization.

This paper makes two main contributions: first, it contributes to literature review related to COVID-19 in emerging countries as it is considered one of the first studies dealing with the impact of COVID-19 on stock returns of firms listed in EGX 30, while previous studies of this paper were trying to measure the effect of COVID-19 on market returns as 
The impact of COVID-19 pandemic outbreak on the Egyptian firms' stock returns

Dr/ Mohamed Hamdy Awad

a whole or sectors and not firms stock returns. Second, for the main players on the Egyptian stock market, the results of this study are significant in understanding and predicting stock return behavior during pandemic disease.

The remaining items are organized in the following sections: Section 2 includes The Outbreak of COVID-19, Section 3 related literature, Section 4 discusses data and methods, followed by empirical results, and Section 5 discusses further analyses, with the conclusion included in Section 6.

\section{COVID-19: Outbreak}

The Covid-19 pandemic epidemic like a storm that darkened the world (Yan et al., 2020) and it is something that the world perhaps has never encountered before (Barua, 2020). The outbreak started at the end of 2019 in Wuhan, China. Amid the rapid dissemination of this virus, the World Health Organization ( WHO ) declared COVID-19 a global emergency on 30 January 2020 (Liu et al., 2020). So far, The United States of America, Brazil, the Russian Federation, India, the United Kingdom, Spain, and Italy are among the largest countries in the world with confirmed cases. The outbreak center has increasingly spread from China to Europe and the United States (He et al., 2020). Over the past five months, this pandemic has brought about a dramatic global rise in the number of infected cases and deaths. The number of cases and deaths confirmed globally is shown in Figures 1. As of 21 May 2020, about 4,96 million cases have been infected worldwide, with 
The impact of COVID-19 pandemic outbreak on the Egyptian firms' stock returns

Dr/ Mohamed Hamdy Awad

around 328 thousand deaths.

In Egypt, the Egyptian Ministry of Health and the population reported the first detected case of the COVID-19 on February 14, 2020, for a foreign citizen. infects rates were very low since the beginning of the epidemic, then this rate began to increase with the entry of the Islamic holy month and Eid AlFitr because people went out to buy their food supplies. as $21 \mathrm{st}$ May 2020, the number of infected cases 15,003, with 969 death cases. The highest fatality rate in Egypt was on the 13th of April 2020, when the rate was 7.60\%. Figures 2 Displays Egypt's total number of reported cases and deaths.

Figure 1: Global number of COVID-19 infections and deaths Global number of COVID-19 infections and deaths

total infected cases $\rightleftharpoons$ total deaths

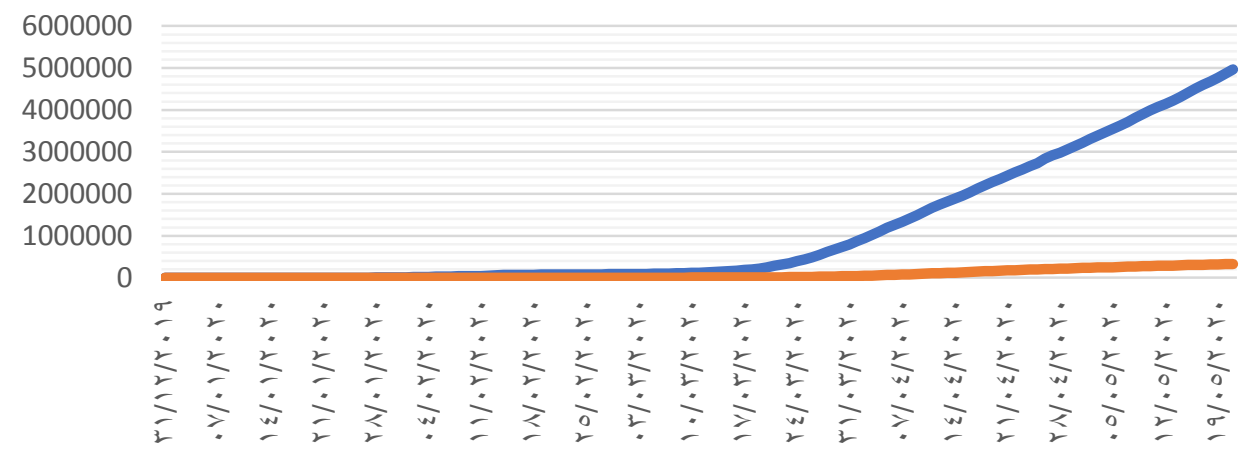

Source: author, based on data from European Centre for Disease Prevention and Control 
The impact of COVID-19 pandemic outbreak on the Egyptian firms' stock returns Dr/ Mohamed Hamdy Awad

Figure 2: Egypt's total number of reported cases and deaths Egypt 's total number of reported cases and deaths

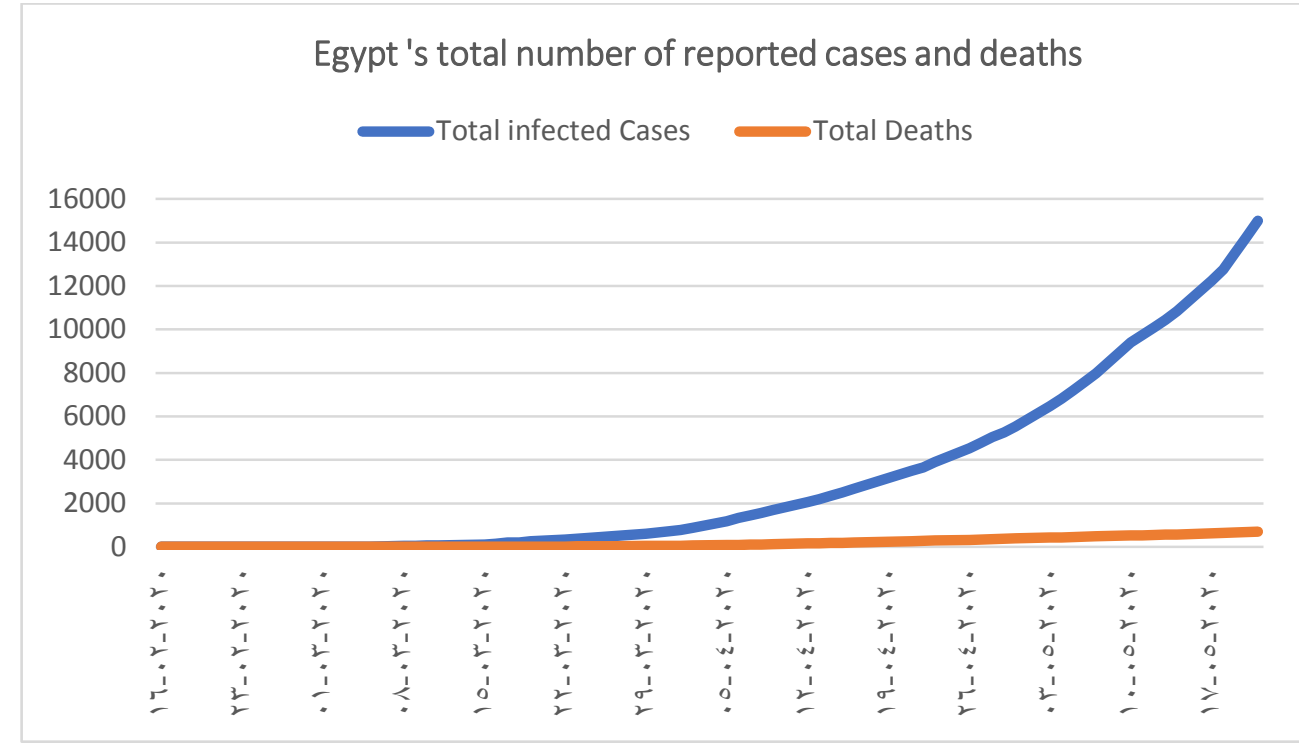

Source: author, based on data from the Egyptian Ministry of Health and population

\section{Literature review}

The COVID-19 has become a global phenomenon, because of the fast blowout of it in all countries of the globe, infecting more than 5 million people around the world until mid-May 2020. Therefore, this pandemic will leave behind consequences on the economy and financial markets.

\subsection{COVID-19 economic impact}

There is an agreement that it is too initial to talk about the economic effects of the COVID-19 epidemic because the 
The impact of COVID-19 pandemic outbreak on the Egyptian firms' stock returns

Dr/ Mohamed Hamdy Awad

pandemic's age has not exceeded six months since the first case was discovered in the People's Republic of China (Yan et al., 2020; Barua, 2020). Nevertheless, COVID-19 jeopardizes economies, whether large or small, developed, or developing. The economic effects of the outbreak are commonly called "coronanomics" (Barua, 2020).

The COVID-19 epidemic will disperse across both micro and macro levels by five waves, according to (Barua, 2020). Initial shutdowns of factories and businesses are the initial consequence of the COVID-19 epidemic and result in a rapid drop in productivity (the first wave). The first wave leads to a demand shock that distorts the supply chain and interrupts human flows between countries. As a result, trade flows of goods and services (the second wave) are being reduced. The reduction in production would undoubtedly lead to a decline in aggregate supply, although demand for vital products (food and medicine) may increase. The reduction in stocks of products and services would lead to a rise in fundamental costs, and the state will use imports from other nations that suffer from the same crisis, which would result in a decrease in the world's production of goods and services (the third wave). Under these conditions, firms resort to layoffs, this leads to an increase in the problem of unemployment, which in turn leads to a decrease in the rate of economic growth (the fourth wave). It is recognized that the next stage of low economic growth is 
The impact of COVID-19 pandemic outbreak on the Egyptian firms' stock returns

Dr/ Mohamed Hamdy Awad

stagnation and economic recession if no effective measures are taken to counter this epidemic.

In this context, Zhang et al. (2020); McKibbin \& Fernando (2020) indicated that the epidemic has a major longand short-term economic implications. Several countries implement stringent quarantine measures in the short term, with dramatically reduced commercial operations. Thus, mass unemployment and market collapses can have the long-term implications of this pandemic.

Gormsen \& Koijen (2020) tried to measure the response from investors to COVID-19 about economic growth. Their annual dividends growth estimates in the US and the EU declined 28\%, 22\% respectively by March 25, while their GDP growth expected to decline by $2.2 \%$ in the US and $2.8 \%$ in the EU. Moreover, in the first quarter of 2020, China (Ayittey et al., 2020 ) is expected to lose up to $\$ 62$ billion, while in the same period the world is expected to lose over $\$ 280$ trillion. claimed in America that COVID-19 raised the rate of unemployment, reduced working hours, and the involvement of the labor force and had a little meaningful effect on incomes (Béland et al., 2020). AlAli (2020) reported that in the first quarter of 2020 GDP of France was expected to decline by $6 \%$ and in German by $5 \%$ due to the COVID-19. The early predictions for the COVID-19 epidemic were calculated through 7 separate scenarios (McKibbin \& Fernando, 2020). These scenarios 
The impact of COVID-19 pandemic outbreak on the Egyptian firms' stock returns

Dr/ Mohamed Hamdy Awad

illustrate the magnitude of costs that could well be reduced in all economies fewer developing countries through higher expenditure in public health services. If COVID-19 becomes a global pandemic, the cost can escalate rapidly.

In Africa, one of the studies concluded that the private sector in Africa is facing a very severe recession because of the corona virus. This puts more than 20 million jobs at risk. Also, pointed out that the effects of the virus Corona-19 on Egypt, according to the owners of hotels and tour guides, the number of visits decreased to $10 \%$ of its normal level, as some hotels reported a zero-occupancy rate. $80 \%$ of future bookings have been canceled in recent days. Airlines alone will lose 2.25 billion Egyptian pounds (Bilal et al., 2020). claimed in Egypt that COVID-19 decrease national GDP by between 0.7 and $0.8 \%$ (Breisinger et al., 2020). In this context, it is anticipated that the Egyptian government will lose around USD 1 billion monthly in tourism revenue with a reduction of remittances by USD 2.3 billion during the period from April to June (OECD, 2020b).

Finally, policymakers must move urgently and aggressively to tackle the corona virus and its effects on the economy. Governments must ensure that infectious outbreaks are successfully avoided and that healthcare services and staff are protected by well-targeted programs and secure the income of disadvantaged social classes and enterprises during the 
The impact of COVID-19 pandemic outbreak on the Egyptian firms' stock returns

Dr/ Mohamed Hamdy Awad

outbreak of a virus (OECD, 2020a). In line with as stated, Evans (2020) introduced some political solutions that represent cooperation between governments and stakeholders to curb the pandemic of a corona virus.

To fight the economic effects of the COVID-19 in Egypt, the President Al-Sisi announced the allocation of 100 billion EGP (USD 6.4 billion equivalent to $2 \%$ of GDP) to fund a comprehensive plan to combat the corona virus. The Government has announced various tax measures covering both people and companies. Egypt`s Central Bank cut interest rates to historic lows: it reduced the overnight deposit rate by 300 basis points to $9.25 \%$ and the lending rate to $10.25 \%$. The Ministry of Workforce has allocated EGP 50 million (USD 2.9 million) for irregular workers, including women, who lost their job due to the corona virus (OECD, 2020b). However, McKibbin \& Fernando (2020) showed the evolution of the disease and its economic impact is highly uncertain which makes it difficult for policymakers to formulate an appropriate macroeconomic policy response.

\subsection{Impacts on stock markets returns}

The pandemic consequences of COVID-19 are not only for public health but also for trade and travel, the food and tourism, IT, and the supermarket chains. It is acknowledged that these sectors or activities consider the key drivers of capital markets (Chang et al., 2020; Yan et al., 2020; Evans, 2020). 
The impact of COVID-19 pandemic outbreak on the Egyptian firms' stock returns

Dr/ Mohamed Hamdy Awad

Ongoing weaker economic growth and a high degree of uncertainty about a pandemic's potential progress contributes to higher volatility equity and high foreign exchange fluctuation (Financial Stability Board, 2020). During pandemics periods, the investor's emotions have a major impact on financial markets. Investors behave optimistically when there is a recovery in financial markets; on the contrary, they behave with pessimistic when there is a decline in the markets because of the existence of a specific pandemic.

From the perspective of the effects of COVID-19 on investor sentiment, Liu et al. (2020) showed that the Investor's concern was a mediator and communication channel of the COVID-19 epidemic effect on financial markets. They also note a significant negative impact on stock returns in all the countries and regions affected by the COVID-19 outbreak. They were consistent with the previous results (He et al., 2020; Çitak et al., 2020). In this context, Papadamou et al. (2020) demonstrated that the direct association between investor attention measured by Google search metrics COVID-19 and market volatility is causal positive.

From the perspective of the effects of COVID-19 on capital markets, the findings show that the increase in the number of cases and deaths correlated with the COVID-19 affected the volatility of Dow Jones and S\&P 500 indices (Onali, 2020). The previous result was also reported by 
The impact of COVID-19 pandemic outbreak on the Egyptian firms' stock returns

Dr/ Mohamed Hamdy Awad

(Yilmazkuday, 2020), and the negative influence of COVID-19 cases was mainly noted in the US on the S\&P 500 index in March 2020. The financial market results also respond adversely to the COVID-19 epidemic in the U.S. (Alfaro et al., 2020). Consistent with this result, Al-Awadhi et al. (2020) showed substantial negative effects on stock returns for all Chinese companies.

The COVID-19 had a negative impact on stock returns in Nigeria in Africa (Adenomon et al., 2020). The results of Egyptian stock markets seem more sensitive to cumulative mortality indicators than daily deaths, and new cases more sensitive than the cumulative COVID-19 cases (Elsayed \& Elrhim, 2020). Using an international sample of 6 countries Alber (2020), it was concluded that market returns seem to be more sensitive to COVID -19 cases than deaths and to the COVID-19 cumulative indicators than the new indicators. Moreover, the spread of the COVID -19 on China, France, Germany, and Spain's stock-market return is negative, whereas these effects for Italy and the United States have not been confirmed. Further, Zaremba et al. (2020) concluded, when using stock information from 67 countries in the period January to April 2020 government policies such as cancellation of public events are key contributors to the increased volatility in the stock market.

From the perspective of the severity of the impact of 
COVID-19 on financial markets, Zhang et al. (2020), the stock market reactions depended on the severity of COVID-19 for each country. Furthermore, Baker et al. (2020) showed that the stock market has been so strongly affected by the COVID-19 more than the previous infectious diseases like the Spanish Flu. Based on the previous analysis of the literature review, research hypotheses can be formulated as follows:

H1: the COVID-19 outbreak measured by daily growth in total confirmed cases and in total confirmed deaths has a negative effect on the stock returns of listed firms in EGX 30.

H2: the COVID-19 outbreak daily cumulative reported COVID19 cases and deaths have a negative effect on the stock returns of listed firms in EGX 30.

\section{Data and methodology}

This study will be relying on panel data to test the influence of COVID-19 on a firm's stock returns instead of an event study. Because use the panel data contribute to making multicollinearity is less and Controlling the impact of omitted variables and heterogeneity assumptions (Smith \& Hsiao, 1988). And not relying on the event study is since the COVID19 is still continuous and it is expected that a second wave will occur from it. Stock returns are estimated as: 


$$
\begin{gathered}
\mathrm{SR}_{\mathrm{i}, \mathrm{t}}=\alpha+\beta 1 \mathrm{DGCC}_{\mathrm{i}, \mathrm{t}}+\beta 2 \mathrm{DGCD}_{\mathrm{i}, \mathrm{t}}+\beta 3 \mathrm{LTVOL}_{\mathrm{i}, \mathrm{t}+} \beta 4 \\
\mathrm{LMCAP}_{\mathrm{i}, \mathrm{t}}+\varepsilon_{\mathrm{i}, \mathrm{t}}(1) \\
\mathrm{SR}_{\mathrm{i}, \mathrm{t}}=\alpha+\beta 1 \mathrm{LDCC}_{\mathrm{i}, \mathrm{t}}+\beta 2 \mathrm{LDCD}_{\mathrm{i}, \mathrm{t}}+\beta 3 \mathrm{LTVOL}_{\mathrm{i}, \mathrm{t}+} \beta 4 \mathrm{LMCAP}_{\mathrm{i}, \mathrm{t}} \\
+\varepsilon_{\mathrm{i}, \mathrm{t}}(2)
\end{gathered}
$$

Where SR i,t is the stock return, DGCC i,t is the daily growth in total confirmed cases, DGCD i,t is the daily growth in total confirmed deaths the LDCC $\mathrm{i}, \mathrm{t}$ is the natural logarithm of daily cumulative cases, LDCD i,t is the natural logarithm of daily cumulative deaths. The firm-specific characteristics include the natural logarithm of daily trading volume (LTVOLi,t) and the natural logarithm of daily market capitalization (LMCAPi,t). the stock return was calculated by a change in closing price for firms' stocks and growth rate for confirmed cases was calculate by new cases divided by total confirmed cases in the previous day.

Data related to the number of COVID-19 reported cases and deaths at the daily level are obtained from www.flevy.com, this data is consistent with reports issued by the Egyptian Ministry of Health and Population. Daily firms closing stock Price from $16^{\text {th }}$ February 2020 to $21^{\text {st }}$ May 2020 was collected from www.investing.com. the observations lost due to holidays and non-trading days are excluded because it is illogical to set a stock price on non-trading days, to ensure consistency and the real expression on data (30 firms and 2010 observations). 
The impact of COVID-19 pandemic outbreak on the Egyptian firms' stock returns

Dr/ Mohamed Hamdy Awad

For all variables used in this analysis, Table 1 contains descriptive statistics. The mean returns are negative which signifies a loss in stock. The highest daily stock return during the period is $12 \%$ and the lowest is $-14 \%$. The tallest growth in daily total reported cases are $227 \%$ and the greatest growth in daily total cases of death caused by COVID-19 is $100 \%$. The biggest number of daily cumulative cases 15003 (the exponential value for 9616) person and the greatest number of daily cumulative deaths 696 (the exponential value for 9616) person.

Table 1: Descriptive statistics

\begin{tabular}{|c|c|c|c|c|}
\hline Variable & Mean & $\begin{array}{c}\text { Standard } \\
\text { deviation }\end{array}$ & Minimum & Maximum \\
\hline SR & -.005 & .038 & -.144 & .119 \\
\hline DGCC & .118 & .3 & 0 & 2.267 \\
\hline DGCD & .069 & .145 & 0 & 1 \\
\hline LDCC & 5.807 & 3.326 & 0 & 9.616 \\
\hline LDCD & 3.43 & 2.564 & 0 & 6.545 \\
\hline LTVOL & 14.393 & 1.781 & 5.521 & 18.849 \\
\hline LMCAP & 22.336 & 1.052 & 19.78 & 25.562 \\
\hline
\end{tabular}

\section{Empirical results and additional analysis}

\subsection{Empirical results}

Table 2 reports the results of the first and second hypothesis panel data regression. Panel A of the findings 
The impact of COVID-19 pandemic outbreak on the Egyptian firms' stock returns Dr/ Mohamed Hamdy Awad

shows that both on daily growth in total reported cases and daily growth in total COVID-19 deaths has a substantial negative effect on stock returns. Panel B findings indicate that stock returns to cumulative daily cases are significantly negative and cumulative daily deaths were insignificantly positive. Furthermore, trade volume and market capitalization are related positively to stock returns in panels $\mathrm{A}$ and $\mathrm{B}$, but for market capitalization, the relationship is insignificant.

Table 2: Panel data regression results

\begin{tabular}{ccc}
\hline \multicolumn{2}{c}{ Panel A: Total confirmed growth in cases and deaths } \\
\hline & $(1)$ & $(2)$ \\
\hline DGCC & $-0.0259^{* * * *}$ & $-0.0257^{* * * *}$ \\
& $(0.00278)$ & $(0.00278)$ \\
DGCD & $-0.0159^{* * *}$ & $-0.0162^{* * *}$ \\
& $(0.00574)$ & $(0.00575)$ \\
LTVOL & & $0.00124^{* * *}$ \\
& & $(0.000488)$ \\
LMCAP & & 0.000595 \\
& & $(0.000827)$ \\
constant & -0.000458 & -0.0316 \\
& $(0.000979)$ & $(0.0215)$ \\
\hline$R^{2}$ & 0.045 & 0.048 \\
\hline
\end{tabular}

$v \cdot A$

العدد الر ابع • r. ا 
The impact of COVID-19 pandemic outbreak on the Egyptian firms' stock returns Dr/ Mohamed Hamdy Awad

\begin{tabular}{ccc}
\hline & Panel B: Daily cumulative cases and deaths \\
\hline \multirow{2}{*}{ LDCC } & $(1)$ & $(2)$ \\
& $-0.00733^{* * *}$ & $-0.00750^{* * *}$ \\
\multirow{2}{*}{ LDCD } & $(0.000755)$ & $(0.000759)$ \\
& $0.0123^{* * *}$ & $0.0124^{* * *}$ \\
LTVOL & $(0.000979)$ & $(0.000981)$ \\
& & $0.00132^{* * *}$ \\
LMCAP & & $(0.000478)$ \\
& & 0.000616 \\
Constant & & $(0.000807)$ \\
& $-0.00419^{* * *}$ & $-0.0365^{*}$ \\
$R^{2}$ & $(0.00182)$ & $(0.0211)$ \\
\hline
\end{tabular}

Remark. The standard errors are in parentheses; *,**, $* * *$ denote statistical significance at the $10 \%, 5 \%$, and $1 \%$ levels, respectively.

\subsection{Additional analysis}

\subsubsection{Sector analysis}

The thirty firms in the EGX 30 index were divided according to the sectors to which they belong, and it became clear that the real estate sector represents $30 \%$ of the index companies, the non-bank financial services sector represents 
about $17 \%$ of the index companies and the basic resources sector represents $10 \%$ of the index companies. Each sector of the following sectors: banks, food, beverages and tobacco, industrial goods, services and automobiles, and health care and pharmaceutical sectors represent about $7 \%$ of the index companies. while each sector of the following sectors: it, media, and communications services, contracting and construction engineering, energy and support services, travel and leisure, textile and durables represent $3 \%$ of the index companies. This study measured the effect of daily growth in total confirmed cases on stock returns of the largest three sectors and it did not address the rest of the sectors because of the small number of firms within each sector. Outbreak COVID-19 has a negative effect on the stock returns of the largest three sectors, the findings in Table 3 suggest.

\subsubsection{Market capitalization analysis}

The study aims to assess the impact of the COVID-19 outbreak on stock market returns of large and small market capitalization stocks. All stocks were ranked based on their market capitalization and use the 50th percentile as a breakpoint between large and small stocks. The researcher uses a dummy variable that takes the value one if stock (i) is in large 50th percentile, and zero otherwise. The results of the dummy variable presented in table 4 suggest that large 
The impact of COVID-19 pandemic outbreak on the Egyptian firms' stock returns Dr/ Mohamed Hamdy Awad

market capitalization stocks have a significant positive effect on returns than small market capitalization stocks.

Table 3: Panel regression results for the sectors

\begin{tabular}{cccc}
\hline Sectors & $\begin{array}{c}\text { Non-banks financial } \\
\text { services }\end{array}$ & Real state & Basic resources \\
\hline DGCC & $-0.0358^{* * *}$ & $-0.0262^{* * *}$ & $-0.0321^{* * *}$ \\
& $(0.00684)$ & $(0.00502)$ & $(0.00938)$ \\
LTVOL & 0.000816 & 0.000907 & 0.00357 \\
& $(0.00127)$ & $(0.00104)$ & $(0.00331)$ \\
LMCAP & -0.00119 & 0.000466 & 0.00699 \\
& $(0.00291)$ & $(0.00175)$ & $(0.0184)$ \\
Constant & 0.0115 & -0.0258 & -0.205 \\
& $(0.0676)$ & $(0.0459)$ & $(0.416)$ \\
\hline$R^{2}$ & 0.078 & 0.044 & 0.062
\end{tabular}

Remark. The standard errors are in parentheses; $*, * *$, $* * *$ denote statistical significance at the $10 \%, 5 \%$, and $1 \%$ levels, respectively. 
The impact of COVID-19 pandemic outbreak on the Egyptian firms' stock returns Dr/ Mohamed Hamdy Awad

Table 4: Panel regression results based on market capitalization

(1)

DGCC

LTVOL $-0.0258 * * *$

(0.00278)

$0.00109 * *$

(0.000469)

DMCAP

Constant

$-0.0172 * *$

$(0.00682)$
(2)

$-0.0257 * * *$

(0.00278)

$0.00141 * * *$

$(0.000508)$

$0.00302 *$

(0.00181)

$-0.0234 * * *$

(0.00776)

\begin{tabular}{lll}
\hline$R^{2}$ & 0.044 & 0.045
\end{tabular}

Remark. DMCAP is a dummy variable that takes the value one if stock (i) is in large 50th percentile and zeroes otherwise. The standard errors are in parentheses; $*, * *, * * *$ denote statistical significance at the $10 \%, 5 \%$, and $1 \%$ levels, respectively.

\section{Conclusion}

The COVID-19 has resulted in turmoil not only in the global economic activity but also in financial markets around the world. This paper has investigated the effects of the COVID-19 outbreak on stock returns of firms in Egyptian markets. The results, based on data from $16^{\text {th }}$ February 2020 to $21^{\text {st }}$ May 2020, suggest that both the daily growth in total 
confirmed cases and in total cases of death caused by COVID19 have significant negative effects on stock returns across all listed firms in EGX 30 index. In addition, stock market returns are negatively related to daily cumulative COVID-19 cases and positively to daily cumulative COVID-19 deaths.

Finally, the research see that What happened in the past happens in the future? therefore, the COVID-19 will have negative effects in the short term, as happened in previous epidemic diseases, and the financial markets will improve in the long term unless there are new surprises that the COVID-19 shows us. Hence, speculators in financial markets buy stocks whose prices have declined in the crisis period to achieve profits from them in the long term. 
The impact of COVID-19 pandemic outbreak on the Egyptian firms' stock returns Dr/ Mohamed Hamdy Awad

\section{$\underline{\text { References }}$}

Adenomon, M. O., Maijamaa, B., \& john, D. O. (2020). On the Effects of COVID-19 outbreak on the Nigerian Stock Exchange performance: Evidence from GARCH Models. Mathematics \& Computer Science. https://doi.org/10.20944/preprints202004.0444.v1

Al-Awadhi, A. M., Al-Saifi, K., Al-Awadhi, A., \& Alhamadi, S. (2020). Death and contagious infectious diseases: Impact of the COVID-19 virus on stock market returns. Journal of Behavioral and Experimental Finance, 27, 100326.

AlAli, M. S. (2020). Risk Velocity and Financial Markets Performance: Measuring the Early Effect of COVID-19 Pandemic on Major Stock Markets Performance. International Journal of Economics and Financial Research, 6(4), 76-81.

Alber, N. (2020). The Effect of Coronavirus Spread on Stock Markets: The Case of the Worst 6 Countries. Available at SSRN 3578080.

Alfaro, L., Chari, A., Greenland, A., \& Schott, P. (2020). Aggregate and Firm-Level Stock Returns During Pandemics. In SSRN Electronic Journal. https://doi.org/10.2139/ssrn.3562034

AmCham Egypt. (2020). Impacts of COVID-19 Pandemic on Egypt's Economy (pp. 1-10). https://www.amcham.org.eg/informationresources/covid-19-response/economic-impact-of-covid-19-a-researchnote-by-amcham-egypt

Ayittey, F. K., Ayittey, M. K., Chiwero, N. B., Kamasah, J. S., \& Dzuvor, C. (2020). Economic impacts of Wuhan 2019-nCoV on China and the world. Journal of Medical Virology, 92(5), 473-475. https://doi.org/10.1002/jmv.25706

Baker, S. R., Bloom, N., Davis, S. J., Kost, K., Sammon, M., \& Viratyosin, 
The impact of COVID-19 pandemic outbreak on the Egyptian firms' stock returns

Dr/ Mohamed Hamdy Awad

T. (2020). The Unprecedented Stock Market Reaction to COVID-19. In The Review of Asset Pricing Studies. https://doi.org/10.1093/rapstu/raaa008

Baldwin, R., \& di Mauro, B. W. (2020). Economics in the Time of COVID19. A VoxEU. Org Book, Centre for Economic Policy Research, London. Accessed, 26.

Barua, S. (2020). Understanding Coronanomics: The economic implications of the coronavirus (COVID-19) pandemic. SSRN Electronic Journal Https://Doi Org/10/Ggq92n.

Béland, L.-P., Brodeur, A., \& Wright, T. (2020). The short-term economic consequences of COVID-19: Exposure to disease, remote work and government response. IZA Discussion Paper, 90. www.iza.org

Bilal, S., Griffith-Jones, S., Kapoor, S., Karingi, S., Songwe, V., \& te Velde, D. W. (2020). Saving Africa's private sector jobs during the coronavirus pandemic. ECDPM, ODI, Re-Define, UNECA, 15.

Breisinger, C., Abdelatif, A., Raouf, M., \& Wiebelt, M. (2020). COVID-19 and the Egyptian economy: Estimating the impacts of expected reductions in tourism, Suez Canal revenues, and remittances. In MENA Regional Program Policy Note 04. Cairo: International Food Policy Research Institute (Vol. 4, Issue March). Intl Food Policy Res Inst. https://doi.org/10.2499/p15738coll2.133663

Chang, C.-L., McAleer, M., \& Wong, W.-K. (2020). Risk and Financial Management of COVID-19 in Business, Economics and Finance. In Journal of Risk and Financial Management (Vol. 13, Issue 5, p. 102). Multidisciplinary Digital Publishing Institute. https://doi.org/10.3390/jrfm13050102

Çitak, F., Bagci, B., IcSahin, E. E., Holcs, S., \& Sakinc, I.Ilker. (2020). 
The impact of COVID-19 pandemic outbreak on the Egyptian firms' stock returns

Dr/ Mohamed Hamdy Awad

Review of stock markets' reaction to COVID-19 news: fresh evidence from Quantile-on-Quantile regression approach. Available at SSRN 3596931 .

Elsayed, A., \& Elrhim, M. A. (2020). The Effect Of COVID-19 Spread On Egyptian Stock Market Sectors. Available at SSRN 3608734.

Evans, O. (2020). Socio-economic impacts of novel coronavirus: The policy solutions. BizEcons Quarterly, 7, 3-12.

Fernandes, N. (2020). Economic effects of coronavirus outbreak (COVID19) on the world economy. Available at SSRN 3557504.

Financial Stability Board. (2020). COVID-19 pandemic: Financial stability implications and policy measures taken (Issue April, pp. 1-14). https://www.mendeley.com/catalogue/869fb1e2-53ee-370d-a3658b7ee8f56ea5/?utm_source=desktop\&utm_medium $=1.19 .5 \& u t m \_c a m$ paign=open_catalog\&userDocumentId=\%7Bd908f626-af00-4777b25e-32cc6474d6f3\%7D

Gormsen, N. J., \& Koijen, R. S. J. (2020). Coronavirus: Impact on stock prices and growth expectations. University of Chicago, Becker Friedman Institute for Economics Working Paper, 2020-22.

He, Q., Liu, J., Wang, S., \& Yu, J. (2020). The impact of COVID-19 on stock markets. Economic and Political Studies, 1-14.

IMF. (2020). The Great Lockdown. In World Economic Outlook (Vol. 1, Issue April, pp. 1-37). https://blogs.imf.org/2019/07/23/sluggishglobal-growth-calls-for-supportive-policies/

Liu, H., Manzoor, A., Wang, C., Zhang, L., \& Manzoor, Z. (2020). The COVID-19 outbreak and affected countries stock markets response. International Journal of Environmental Research and Public Health, 17(8), 2800. 
The impact of COVID-19 pandemic outbreak on the Egyptian firms' stock returns Dr/ Mohamed Hamdy Awad

McKibbin, W. J., \& Fernando, R. (2020). The Global Macroeconomic Impacts of COVID-19: Seven Scenarios. SSRN Electronic Journal. https://doi.org/10.2139/ssrn.3547729

OECD. (2020a). Coronavirus: The world economy at risk. In OECD Interim Economic Assessment (Issue March, pp. 1-15). http://www.oecd.org/berlin/publikationen/Interim-EconomicAssessment-2-March-2020.pdf

OECD. (2020b). The COVID-19 Crisis In EGYPT (pp. 1-5). https://www.oecd.org/mena/competitiveness/The-Covid-19-Crisis-inEgypt.pdf

Onali, E. (2020). Covid-19 and stock market volatility. Available at SSRN 3571453.

Papadamou, S., Fassas, A., Kenourgios, D., \& Dimitriou, D. (2020). Direct and Indirect Effects of COVID-19 Pandemic on Implied Stock Market Volatility: Evidence from Panel Data Analysis. Mpra.

Smith, R. J., \& Hsiao, C. (1988). Analysis of Panel Data. In Economica (Vol. 55, Issue 218). Cambridge university press. https://doi.org/10.2307/2554479

Taubenberger, J. K., \& Morens, D. M. (2006). 1918 Influenza: The mother of all pandemics. Emerging Infectious Diseases, 12(1), 15-22. https://doi.org/10.3201/eid1209.05-0979

Velde, F. (2020). The Economy and Policy in the Coronavirus Crisis to Date. Presentation at a Panel Session for the Brookings Papers on Economics Activity, 20. https://www.google.com/search?q=hearing+is\&oq=hearing+is\&aqs=ch rome..69i57j013j46j013.1344j0j7\&sourceid=chrome\&ie=UTF-8

Yan, B., Stuart, L., Tu, A., \& Zhang, Q. (2020). Analysis of the Effect of 
The impact of COVID-19 pandemic outbreak on the Egyptian firms' stock returns Dr/ Mohamed Hamdy Awad

COVID-19 on the Stock Market and Investing Strategies. SSRN Electronic Journal, 3563380. https://doi.org/10.2139/ssrn.3563380

Yilmazkuday, H. (2020). COVID-19 Effects on the S\&amp;P 500 Index. SSRN Electronic Journal. https://doi.org/10.2139/ssrn.3555433

Zaremba, A., Kizys, R., Aharon, D. Y., \& Demir, E. (2020). Infected Markets: Novel Coronavirus, Government Interventions, and Stock Return Volatility around the Globe. Finance Research Letters, 101597. https://doi.org/10.1016/j.frl.2020.101597

Zhang, D., Hu, M., \& Ji, Q. (2020). Financial markets under the global pandemic of COVID-19. Finance Research Letters, 101528. https://doi.org/10.1016/j.frl.2020.101528 